\title{
Bizarre Parosteal Osteochondromatous Proliferation of Long Bones: Two New Cases and Literature Study
}

\author{
Ahmet Kapukaya ${ }^{a}$, Celil Alemdar ${ }^{\mathrm{a}}$, Rana Isik ${ }^{\mathrm{b}}$, Bekir Yavuz Ucar ${ }^{\mathrm{a}, \mathrm{d}}$, Ibrahim Azboy, \\ Mehmet Gem ${ }^{\mathrm{a}}$, Abdurrahim Dusak ${ }^{\mathrm{c}}$
}

\begin{abstract}
In research on tumors of mesenchymal origin, although the type localized in the short, tubular bones has been evaluated in detail, there have been no reports to date regarding the clinical, radiological and treatment characteristics of the type localized in the long bones. In this study, Nora's lesions localized in the long bones were investigated in terms of their characteristics and behavior. An extensive literature review was performed using PubMed, MEDLINE (1983 - 2012) and Google Scholar. Search terms included "bizarre parosteal osteochondromatous proliferation" (BPOP) and "Nora's lesion". The literature search yielded 88 articles and a total of 43 patients. The median age of the cases was 26 years. BPOP occurred with equal frequency in men and women. The most frequent sites of involvement were the femur $(25 \%)$ and the ulna $(23 \%)$. Plain radiographs of 20 cases were available, but only a small number of cases had CTs $(\mathrm{n}=11)$ and MRIs $(\mathrm{n}=12)$ performed. It was determined that $66 \%$ of the lesions led to cortical changes, while $23.5 \%$ led to medullary invasion or soft tissue infiltration. As to treatments, "simple excision" (intralesional) was performed on seven lesions, marginal resection was performed in nine patients, wide resection was performed in two patients, "shark-bite" surgery was performed in one patient and "shave excision" was performed in one patient. The mean follow-up period was 30.9 months. Local recurrence rate was $18.75 \%$. Clinically and in terms of radiological images, we believe that this lesion observed in the long bones consists of four phases: stages I, II, III and IV. We believe this type of lesion demonstrates no spontaneous recovery, and that it is a progressive lesion
\end{abstract}

Manuscript accepted for publication March 11, 2014

${ }^{\mathrm{a} D e p a r t m e n t ~ o f ~ O r t h o p a e d i c s ~ a n d ~ T r a u m a t o l o g i a, ~ D i c l e ~ U n i v e r s i t y ~}$ Medical Faculty, Diyarbakir, Turkey

${ }^{\mathrm{b}}$ Department of Plastic Surgery, Diyarbakir Training and Research Hospital, Diyarbakir, Turkey

${ }^{c}$ Department of Radiology, Dicle University Medical Faculty, Diyarbakir, Turkey

${ }^{\mathrm{d}}$ Corresponding author: Bekir Yavuz Ucar, Department of Orthopaedics and Traumatology, Dicle University Medical Faculty, Diyarbakir, Turkey. Email: drbyucar@yahoo.com

doi: http://dx.doi.org/10.14740/jmc1624w involving cortical destruction and medullary infiltration. As such, we consider marginal resection to be the appropriate technique for treating this lesion.

Keywords: Bizarre parosteal osteochondromatous proliferation; Nora's lesion; Long bones

\section{Introduction}

Bizarre parosteal osteochondromatous proliferation (BPOP) is a rare lesion of the bone, described by Nora et al [1]. In their original paper, all lesions affected the tubular bones of the hands and feet. In the original series of Nora et al, only two of 35 cases were localized in the long bones. Ten years after the publication of that study, Meneses et al [2] presented a second study from the same clinic, consisting of 65 cases, none of which were Nora's cases. In the Meneses study, localization in the long bones was observed in 17 of the 65 cases. Subsequent reports, however, have identified lesions in the long bones [3-6]. Nora's lesion is a mesenchymal lesion of the bone, characterized by exophytic growth involving bone, fibrous tissue and cartilage. BPOP is classically a broad-based calcified lesion attached to the cortex without any periosteal new bone formation, and with an intact underlying cortical bone [6-8]. This lesion, commonly observed in the short tubular bones, is localized in the long bones in approximately $30 \%$ of cases [2]. It has been reported in cases with progressive characteristics $[9,10]$, and it has radiological features in long bones that differ from those observed in short, tubular bones. These features have necessitated a review of this type of tumor localized in the long bones, as the characteristics and behavior of such lesions have not yet been fully elucidated. High rates of recurrence have been reported in the follow-up of these lesions, which are often considered malignant bone tumors that require the application of surgical techniques, with high morbidity rates for its treatment. As a result, it has become necessary to perform a thorough review of this disease $[4,11]$. To this end, clinical and radiological presentations, as well as the treatment of patients with such lesions, have been reported. 


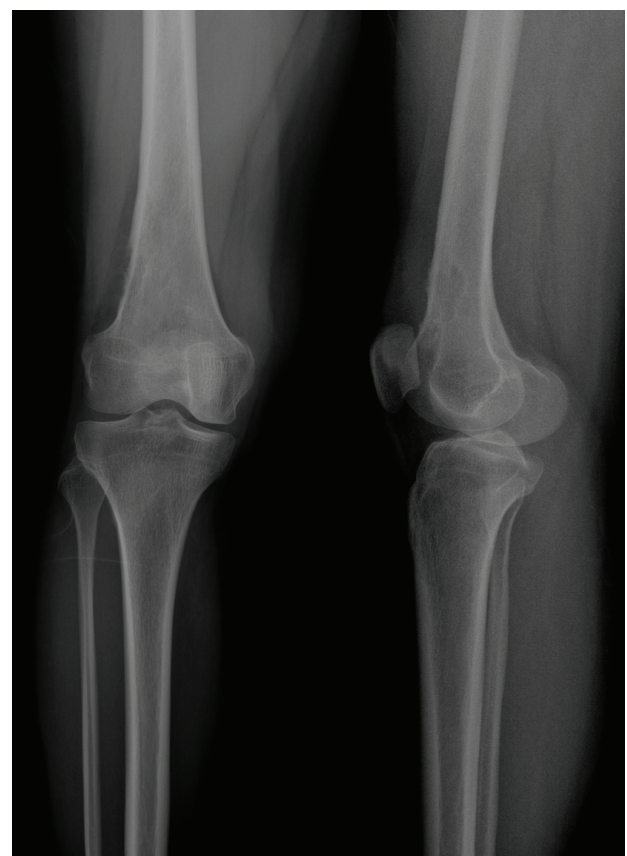

Figure 1. Film obtained 2 years ago during the patient's first admission.

An extensive literature review was performed using PubMed, MEDLINE (1983 - 2012) and Google Scholar. Search terms included "bizarre parosteal osteochondromatous proliferation" and "Nora's lesion". The search was limited to the English language and to human cases. Studies were excluded if the lesions were located in areas other than the long bones. Studies with mixed populations of lesion location were included. The following information was collected from each study: year of publication, age and sex of patients, duration of follow-up, history of trauma, symptoms, size of lesion, plain radiographs, MRI and CT images features, treatment and outcome.

The literature search yielded 88 articles, of which 70 were excluded, for the following reasons: 50 focused on non-long bones (hands, feet, mandible, maxilla and skull); 13 had an English abstract but were written in another language. Seven of these studies were cytogenetic analyses. This review included the results of identified studies. The years of publication were 1983 - 2012, and the total number of patients was 43. All the studies were of level IV and V. A previous published case by us was also included in this study [12].

\section{Case Report}

\section{The First Patient}

The patient was admitted to our polyclinic 2 years ago with

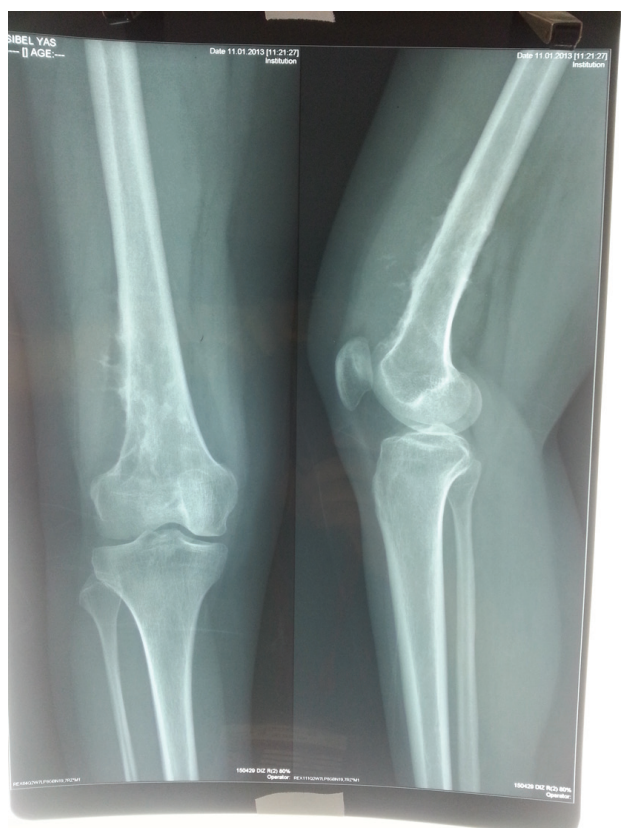

Figure 2. At the end of the second year, plain radiographs demonstrated a calcified, osseous mass extending to the anterolateral and posterior aspects of the distal femur.

a complaint of right knee pain. A physical examination revealed no positive findings, other than local sensitivity. Plain radiography indicated destruction and periosteal reaction in the distal lateral cortex of the femur (Fig. 1). The patient refused further tests and treatment during this admission to the polyclinic, and was later lost to follow-up. The patient was admitted once again, at the end of the second year following her first admission.

In the second admission, the 21-year-old woman presented with a history of a progressive, painful, palpable mass on the posterior, lateral and anterior aspect of the right distal thigh. She reported that the mass had enlarged since she had first noticed it, and she had a history of trauma. A clinical examination revealed a hard, immobile, multilobulated mass. Using plain radiography, the lesion was observed to be large, with evidence of cortical destruction and periosteal new bone formation. The radiographs showed a calcified, osseous mass extending into the anterolateral and posterior aspects of the distal femur (Fig. 2). A computed tomography (CT) scan of the distal femur showed cortical destruction, cortical perforation and periosteal reaction (Fig. 3a, b). Magnetic resonance imaging (MRI) revealed a heterogeneous, lobulated mass wrapped around the knee anteriorly, laterally and posteriorly (Fig. 4a-c). At a macroscopic level, the multilobular mass had wrapped the distal femur, causing destruction in the cortex (Fig. 5a-c). In addition, the mass had perforated the lateral cortex, and medullary infiltration was present. BPOP (Nora's lesion) was diagnosed after histopathological examination. 


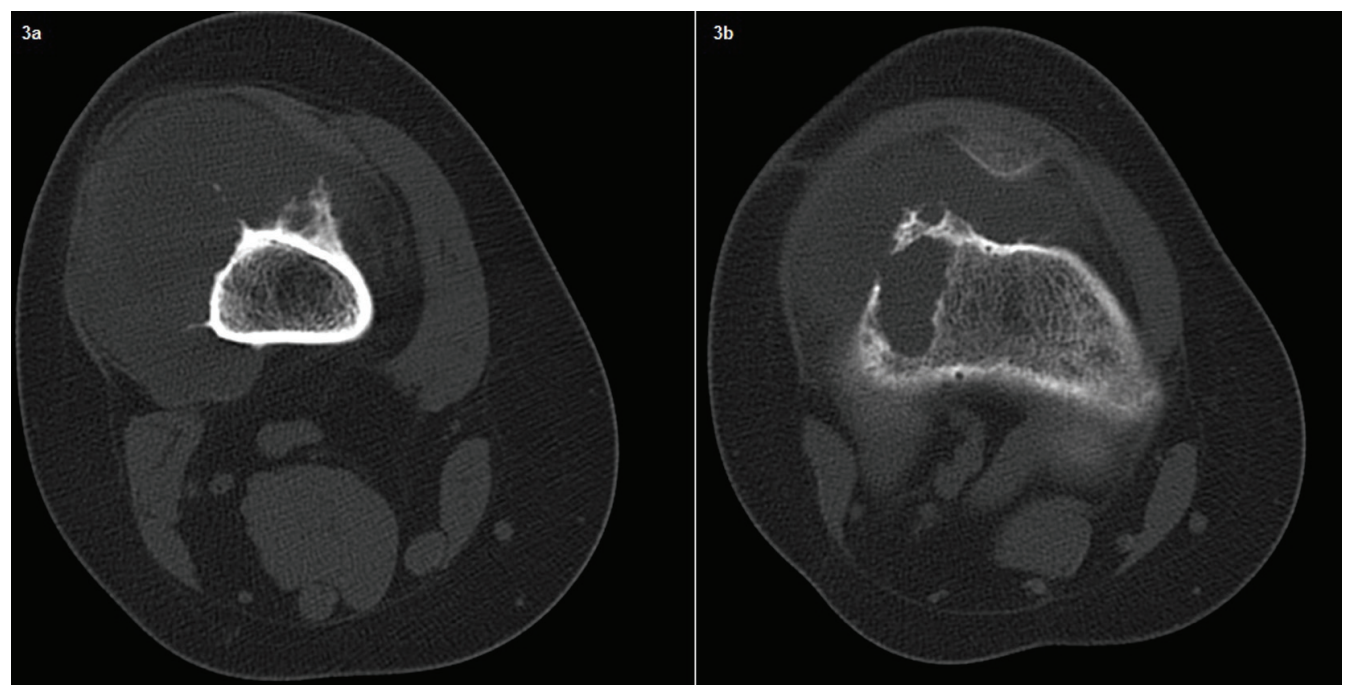

Figure 3. A computed tomography (CT) scan of the distal femur showing cortical destruction, periosteal reaction and cortical perforation.

\section{The Second Patient}

A 19-year-old man presented to our outpatient clinic with a 6-month history of progressive pain in the posterior distal knee. The patient had a history of trauma. Plain radiographs were normal, without any disruption in the bony architecture. In the MRI, the necrotic area was of low signal intensity on T1-weighted images and of high signal intensity on T2weighted images. In the distal epiphysis metaphyseal area, femoral cortical perforation and posterior medullary inva- sion were present due to the mass. A CT scan of the distal femur demonstrated cortical perforation. BPOP (Nora's lesion) was diagnosed after histopathological examination.

The same treatment was administered for both lesions. Marginal resection was performed on the soft tissue component of the lesion. Decortication was performed on the cortical segment of the lesion, and intralesional curettage was performed on its medullary component. In addition, local and combined adjuvant therapy was administered to both the cortical and medullary regions of the lesion, with cautery
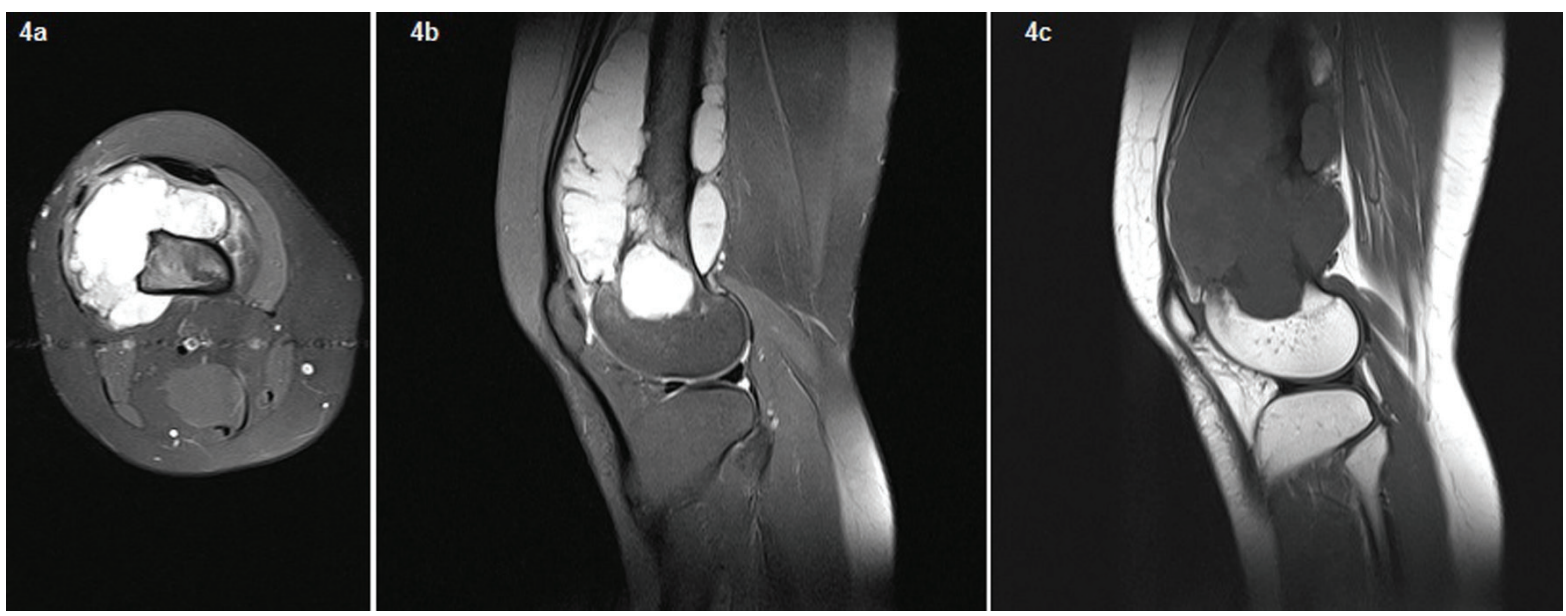

Figure 4. On the MRI, a heterogeneous, lobulated mass wrapped around the knee anteriorly, laterally, and posteriorly. Fig. 3 The necrotic area was of low signal intensity on T1-weighted images and of high signal intensity on T2-weighted images. Femoral cortical destruction as well as lateral, anterior, and posterior irregularity and medullary invasion were present due to the mass. New ossification extended from the femoral cortex into the mass. On T2-weighted gradient imaging, the central portion of the lesion had an inhomogeneous intermediate signal, with a uniformly high signal in the periphery. 

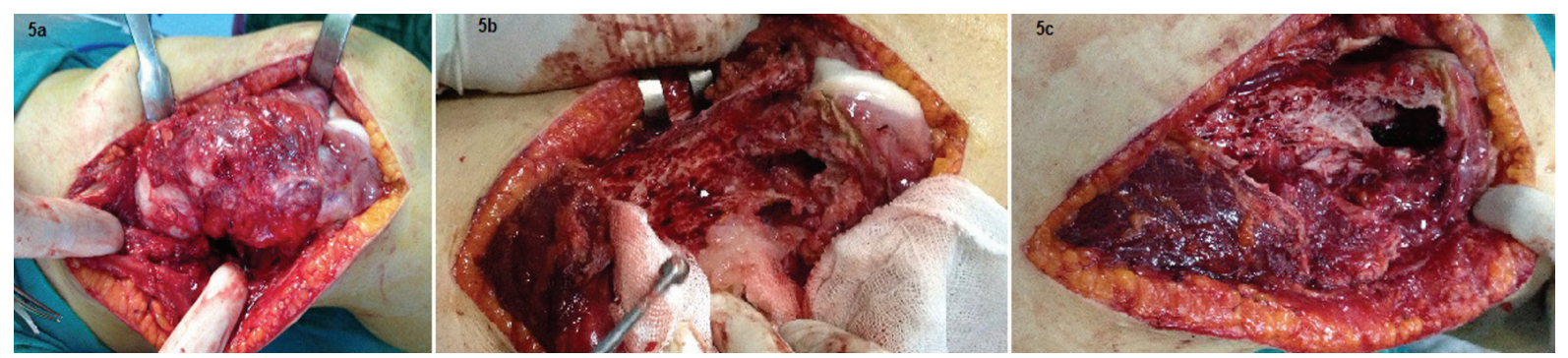

Figure 5. At a macroscopic level, the multilobular mass had wrapped the distal femur, causing destruction in the cortex. In addition, the mass had perforated the lateral cortex, and a medullary infiltration was present.

and phenol. One of the patients was followed for 10 months, while the other patient was followed for 12 months. Local recurrence was not observed in either of these patients.

\section{Clinical Review}

\section{Sex and age}

Information on sex and age was available for 21 of 43 patients. BPOP has no gender predilection, and it can occur at any age. The age distribution of the cases was $10-52$ years (median, 26). BPOP occurs with equal frequency among men and women (ratio of 1:1).

\section{Localization}

Of the 43 cases, 23 were located in the upper limb bones. The most frequent sites were the femur $(25 \%)$ and ulna (23\%), followed by the radius. Twenty cases were localized in the metaphysis of the long bones, five in the diaphysis and one in the epiphysis metaphysis; localization was not defined in 17 of the cases.

\section{Symptoms}

Thirteen patients presented with painful swelling, eight with painless swelling and one with pain only on the posterior of the knee. The remaining 21 had no documented presenting features. Trauma history was inquired about in 21 of the 43 patients, and nine indicated a history of trauma.

\section{Radiological features}

Plain radiographs were available for 20 of the cases, but only a small number of cases had CTs $(\mathrm{n}=11)$ and MRIs $(\mathrm{n}=$ 12) performed (Table 1). Radiological features of the lesions were categorized as soft tissue mass, parosteal calcification, or ossification. Changes in the endosteal and periosteal aspects of the cortex and in the cortical bone itself (cortical destruction, perforation, thickening), changes in the medullary bone (marrow involvement), the presence of a radiolucent line (zone) between the lesion and the adjacent cortex, and soft tissue extension of the lesion were analyzed.

\section{Plain radiographs}

Nine of the cases showed a well-defined, cortical-based, calcified or osseous lesion. In five of the cases, the lesion had a broad base of attachment to the host bone, as well as a thickening cortex. In three of the cases, the margin of the lesion was not clearly defined, and there were lucent areas within lesion itself. One case had a pedunculated mass, one case had periosteal new bone formation and yet another case had a soft tissue density mass. CT provided a better delineation of the relationship between the lesion and the host bone. CT scans were performed on 12 patients. In these cases, the CT showed cortical destruction and perforation, as well as a medullary pattern. In two of the patients, the cortex of the bone was normal. In six patients, the lesions showed cortical destruction or perforation. Three cases had cortical reactive sclerosis. One lesion had a calcified soft tissue mass without any disruption to its bony architecture. MRI scans were performed on 12 patients. In two patients, the MRI revealed marrow involvement, and two patients had soft tissue extension. Lesion size varied between $2 \mathrm{~cm}$ and $10 \mathrm{~cm}$ (mean 4.53 $\mathrm{cm}$ ) (Table 2).

\section{Treatment}

Information regarding surgery technique was obtained for 21 of the patients. "Simple excision" (intralesional) was performed on seven lesions, and marginal resection was performed in seven patients, with marginal resection performed on the soft tissue component in two patients. Intralesional curettage, along with local adjuvant therapy, was administered to the medullary component. Decortication, along with local adjuvant therapy, was administered to the cortical component. A wide resection was performed in two patients, "shark-bite" surgery (removal of a margin of normal bone around the lesion) was performed in one patient and "shave excision" was performed in one patient. Surgical treatment 
Table 1. Patient Demographics and Symptoms

\begin{tabular}{|c|c|c|c|c|c|c|c|c|}
\hline $\begin{array}{l}\text { No. of } \\
\text { papers }\end{array}$ & Study & Year & $\begin{array}{l}\text { No. of } \\
\text { patients }\end{array}$ & Sex/age & Trauma & Symptom & $\begin{array}{l}\text { Involved } \\
\text { bone }\end{array}$ & Localization \\
\hline 1 & Gruber [16] & 2008 & 1 & $\mathrm{M} / 16$ & No & $\mathrm{S} \& \mathrm{P}$ & Ulna & $\mathrm{DM}$ \\
\hline 2 & Bhalla [18] & 2012 & 1 & $\mathrm{M} / 10$ & Yes & $\mathrm{S} \& \mathrm{P}$ & Femur & $\mathrm{DM}$ \\
\hline 3 & Kershen [21] & 2012 & 1 & $\mathrm{~F} / 37$ & No & $\mathrm{S} \& \mathrm{P}$ & Tibia & Diaphysis \\
\hline \multirow[t]{2}{*}{4} & Rybak [10] & 2007 & 2 & $\mathrm{~F} / 16$ & No & $\mathrm{S}$ & Ulna & $\mathrm{DM}$ \\
\hline & & & & $\mathrm{M} / 36$ & & & Radius & $\mathrm{DM}$ \\
\hline \multirow[t]{2}{*}{5} & Abramovici [3] & 2002 & 2 & $\mathrm{~F} / 12$ & No & $\mathrm{S} \& \mathrm{P}$ & Femur & $\mathrm{DM}$ \\
\hline & & & & $\mathrm{M} / 27$ & Yes & $\mathrm{S} \& \mathrm{P}$ & Tibia & PM \\
\hline 6 & Joseph [9] & 2011 & 1 & $\mathrm{~F} / 22$ & Yes & $\mathrm{S}$ & Tibia & PM \\
\hline 7 & Meneses [2] & 1993 & 17 & - & - & - & $\begin{array}{l}\text { Humerus (1) } \\
\text { Ulna (6) } \\
\text { Radius (3) } \\
\text { Femur (3) } \\
\text { Fibula (2) } \\
\text { Tibia (2) }\end{array}$ & Not defined \\
\hline \multirow[t]{3}{*}{8} & Berber [6] & 2011 & 5 & $\begin{array}{l}\text { Not } \\
\text { defined }\end{array}$ & $\begin{array}{l}\text { Not } \\
\text { defined }\end{array}$ & No & Radius & $\begin{array}{l}\text { PM } \\
\text { DM } \\
\text { PM } \\
\text { DM } \\
\text { DM }\end{array}$ \\
\hline & & & & & & & Tibia & PM \\
\hline & & & & & & & Femur (2) & $\mathrm{DM}$ \\
\hline 9 & Cooper [11] & 1993 & 1 & $\mathrm{M} / 37$ & No & $\mathrm{S}$ & Radius & Diaphysis \\
\hline 10 & Helliwell [17] & 2001 & 1 & $\mathrm{M} / 15$ & Yes & $\mathrm{S}$ & Radius & Diaphysis \\
\hline 11 & Bush [4] & 2007 & 1 & $\mathrm{~F} / 51$ & Yes & $\mathrm{S} \& \mathrm{P}$ & Humerus & PEM \\
\hline 12 & Boudova [19] & 1999 & 1 & $\mathrm{M} / 52$ & Yes & P\&S & Femur & PM \\
\hline 13 & Vlychou [5] & 2008 & 1 & $\mathrm{~F} / 30$ & No & $\mathrm{S} \& \mathrm{P}$ & Clavicle & $\mathrm{DM}$ \\
\hline 14 & Ly [20] & 2004 & 1 & $\mathrm{M} / 18$ & Yes & $\mathrm{S} \& \mathrm{P}$ & Humerus & Diaphysis \\
\hline 15 & Hefferman [14] & 2008 & 1 & $\mathrm{~F} / 41$ & No & $\mathrm{S}$ & Ulna & $\mathrm{DM}$ \\
\hline 16 & Nora [1] & 1983 & 2 & $\begin{array}{l}\mathrm{M} / 24 \\
\mathrm{~F} / 21\end{array}$ & $\begin{array}{l}\text { Not } \\
\text { defined }\end{array}$ & $\mathrm{S}$ & $\begin{array}{l}\text { Humerus } \\
\text { Radius }\end{array}$ & $\begin{array}{l}\mathrm{DM} \\
\mathrm{DM}\end{array}$ \\
\hline \multirow[t]{3}{*}{17} & Author cases & New case & 1 & $\mathrm{M} / 19$ & Yes & $\mathrm{P}$ & Femur & DEP \\
\hline & & New case & 1 & $\mathrm{M} / 21$ & Yes & $\mathrm{S} \& \mathrm{P}$ & Femur & $\mathrm{DM}$ \\
\hline & & $2006[12]$ & 1 & $\mathrm{~F} / 27$ & No & $\mathrm{S} \& \mathrm{P}$ & Femur & $\mathrm{DM}$ \\
\hline 18 & Choi [15] & 2001 & 1 & $\mathrm{~F} / 18$ & No & $\mathrm{S}$ & Fibula & $\mathrm{DM}$ \\
\hline
\end{tabular}

S\&P: swelling and pain; PM: proximal metaphysic; DM: distal metaphysic; PEM: proximal epyphisiometaphysis; DEP: distal epyphisiometaphysis. 
Table 2. Radiological Features and Stages of the Lesions

\begin{tabular}{|c|c|c|c|c|c|c|c|}
\hline $\begin{array}{l}\text { No. of } \\
\text { papers }\end{array}$ & X-ray & CT & MRI & $\begin{array}{l}\text { Size of } \\
\text { tumor } \\
(\mathrm{cm})\end{array}$ & C. Dest & M. Inv & Stage \\
\hline 1 & $\begin{array}{l}\text { Cortical-based calcified } \\
\text { and osseous masses }\end{array}$ & $\begin{array}{l}\text { Intensely calcified and } \\
\text { ossified masses }\end{array}$ & $\begin{array}{l}\text { Marrow involvement: No } \\
\text { Soft-tissue extension: No }\end{array}$ & $\begin{array}{l}\text { Not } \\
\text { defined }\end{array}$ & No & No & II \\
\hline 2 & $\begin{array}{l}\text { Broad-based osseous } \\
\text { protuberance masses, } \\
\text { Cortical reactive sclerosis }\end{array}$ & $\begin{array}{l}\text { Exostotic appearing } \\
\text { lesion }\end{array}$ & $\begin{array}{l}\text { Marrow involvement: No } \\
\text { Soft-tissue extension: No }\end{array}$ & 3 & Yes & No & III \\
\hline 3 & $\begin{array}{l}\text { Cortical-based calcified } \\
\text { and osseous masses }\end{array}$ & Not defined & $\begin{array}{l}\text { Marrow involvement: No } \\
\text { Soft-tissue extension: No }\end{array}$ & 5 & No & No & II \\
\hline \multirow[t]{2}{*}{4} & 1. Pedunculated mass & $\begin{array}{l}\text { Pedunculated mass of } \\
\text { mature ossification with } \\
\text { distinct medullary and } \\
\text { cortical components }\end{array}$ & Not defined & 3 & Yes & Yes & IV \\
\hline & $\begin{array}{l}\text { 2. Cortical-based calcified } \\
\text { and osseous masses }\end{array}$ & Not defined & Not defined & $\begin{array}{l}\text { Not } \\
\text { defined }\end{array}$ & Yes & $\begin{array}{l}\text { Not } \\
\text { defined }\end{array}$ & II \\
\hline \multirow[t]{2}{*}{5} & $\begin{array}{l}\text { 1. Cortical involvement } \\
\text { and destruction as well as } \\
\text { focal calcification }\end{array}$ & $\begin{array}{l}\text { Cortical destruction, } \\
\text { Cortical reactive } \\
\text { sclerosis }\end{array}$ & $\begin{array}{l}\text { Marrow involvement: No } \\
\text { Soft-tissue extension: No }\end{array}$ & 4 & Yes & No & III \\
\hline & 2. Soft-tissue density mass & & $\begin{array}{l}\text { Marrow involvement: No } \\
\text { Soft-tissue extension: No }\end{array}$ & $2 \mathrm{~cm}$ & No & No & I \\
\hline 6 & $\begin{array}{l}\text { Well-defined ossified } \\
\text { parosteal lesion }\end{array}$ & Not defined & Not defined & $4 \mathrm{~cm}$ & Yes & $\begin{array}{l}\text { Not } \\
\text { defined }\end{array}$ & III \\
\hline 7 & Not defined & Not defined & Not defined & $\begin{array}{l}\text { Not } \\
\text { defined }\end{array}$ & $\begin{array}{l}\text { Not } \\
\text { defined }\end{array}$ & $\begin{array}{l}\text { Not } \\
\text { defined }\end{array}$ & No \\
\hline 8 & Not defined & Not defined & Not defined & $\begin{array}{l}\text { Not } \\
\text { defined }\end{array}$ & $\begin{array}{l}\text { Not } \\
\text { defined }\end{array}$ & $\begin{array}{l}\text { Not } \\
\text { defined }\end{array}$ & II \\
\hline 10 & $\begin{array}{l}\text { Mushroom-shaped } \\
\text { calcification mass }\end{array}$ & $\begin{array}{l}\text { Cortical involvement } \\
\text { and destruction }\end{array}$ & $\begin{array}{l}\text { Marrow involvement: Yes } \\
\text { Soft-tissue extension: Yes }\end{array}$ & $4 \mathrm{~cm}$ & Yes & Yes & IV \\
\hline 11 & $\begin{array}{l}\text { A surface based, } \\
\text { radiodense lesion }\end{array}$ & $\begin{array}{l}\text { No intramedullary } \\
\text { extension and no } \\
\text { cortical disruption }\end{array}$ & $\begin{array}{l}\text { Marrow involvement: No } \\
\text { Soft-tissue extension: No }\end{array}$ & 6 & No & No & II \\
\hline 12 & Egg-shaped calcification & $\begin{array}{l}\text { No intramedullary } \\
\text { extension and no } \\
\text { cortical disruption }\end{array}$ & Not defined & 5 & No & No & I \\
\hline 13 & $\begin{array}{l}\text { Ill-defined, radiodense } \\
\text { mass }\end{array}$ & Not defined & $\begin{array}{l}\text { Marrow involvement: No } \\
\text { Soft-tissue extension: No }\end{array}$ & $\begin{array}{l}\text { Not } \\
\text { defined }\end{array}$ & Yes & No & II \\
\hline 14 & Cortical-based calcified & $\begin{array}{l}\text { Calcified soft-tissue } \\
\text { mass }\end{array}$ & Not defined & $\begin{array}{l}\text { Not } \\
\text { defined }\end{array}$ & No & No & $\mathrm{I}$ \\
\hline 15 & $\begin{array}{l}\text { Well-defined ossified } \\
\text { lesion }\end{array}$ & $\begin{array}{l}\text { Cortical involvement } \\
\text { and destruction }\end{array}$ & $\begin{array}{l}\text { Marrow involvement: No } \\
\text { Soft-tissue extension: No }\end{array}$ & 2 & Yes & No & III \\
\hline 16 & Not defined & Not defined & Not defined & $\begin{array}{l}\text { Not } \\
\text { defined }\end{array}$ & $\begin{array}{l}\text { Not } \\
\text { defined }\end{array}$ & $\begin{array}{l}\text { Not } \\
\text { defined }\end{array}$ & No \\
\hline \multirow[t]{3}{*}{17} & $\begin{array}{l}\text { 1. Well-defined ossified } \\
\text { parosteal lesion, } \\
\text { thickening cortex }\end{array}$ & Not defined & $\begin{array}{l}\text { Marrow involvement: No } \\
\text { Soft-tissue extension: No }\end{array}$ & 10 & Yes & No & III \\
\hline & 2. Normal & $\begin{array}{l}\text { Cortical involvement } \\
\text { and destruction }\end{array}$ & $\begin{array}{l}\text { Marrow involvement: Yes } \\
\text { Soft-tissue extension: Yes }\end{array}$ & 3 & Yes & Yes & IV \\
\hline & $\begin{array}{l}\text { 3. Ossified parosteal } \\
\text { lesion }\end{array}$ & $\begin{array}{l}\text { Cortical involvement } \\
\text { and destruction }\end{array}$ & $\begin{array}{l}\text { Marrow involvement: Yes } \\
\text { Soft-tissue extension: No }\end{array}$ & 10 & Yes & Yes & IV \\
\hline 18 & $\begin{array}{l}\text { Cortical-based calcified } \\
\text { mass }\end{array}$ & Not defined & Not defined & 5 & $\begin{array}{l}\text { Not } \\
\text { defined }\end{array}$ & No & No \\
\hline
\end{tabular}

C. Dest: cortical destruction; M. Inv: medullary invasion. 
was not conducted in one of the patients.

\section{Recurrence}

Follow-up information was obtained for 13 of the 43 patients, with the follow-up period ranging 10 - 90 months (mean 30.9 months). Information about local recurrence could not be obtained for 27 of the patients. Local recurrence was observed in three of the 16 lesions. One patient experienced four local recurrences within a year. Two of the patients with local recurrence were treated successfully by a second excision, while the other patient was treated with wide excision. Eleven patients described no local recurrence. One of the patients did not undergo any surgical treatment. Other complications included AVN of the humeral head, popliteal aneurysm and fibrosarcoma. No metastases or deaths related to these lesions were reported (Table 3).

\section{Discussion}

Bizarre parosteal osteochondromatous proliferation is a rare, reactive, mineralizing and ossifying mesenchymal lesion that is typically localized on the surfaces of bones in the feet and hands. Although the frequency of the type of lesion that localizes in the long bones is not clearly known, their ratio is estimated at approximately 30\%. The type of lesion localized in the long bones demonstrates behavior that is different in certain respects from lesions localized in the short bones. Lesions observed in the short bones generally lead to complaints of swelling without pain [12]. On the other hand, cases with lesions on the long bones present complaints of painful swelling in eight of the 22 cases. Lesions occurring on long bones can have radiological manifestations distinct from those observed in BPOP in the short bones. Classically, the radiographic appearance of lesions observed in the short bones involves a well-defined pedunculated or broad-based osseous protuberance along the cortical surface of the bone $[13,14]$. The underlying bone is characteristically normal in appearance, without evidence of medullary invasion, reactive sclerosis, or periostitis; no periosteal new bone formation is involved $[3,15,16]$. Cortical and medullary continuity of the lesion is confirmed by CT. MRI can demonstrate more specific attributes of the lesion, which are associated with the normal underlying bone and adjacent soft tissues. Lesions localized in the long bones can demonstrate aggressive radiological progression. The imaging appearance of certain lesions observed in the long bones seem to be more aggressive than previously thought, demonstrating infiltration of the soft tissue at the periphery and cortical destruction along with medullary infiltration [3, 9-12, 14, 17, 18]. In this study, information regarding cortical changes could be obtained only for 18 of the 43 lesions. Cortical changes (cortical thickening, cortical destruction, cortical perforation and periosteal reaction) were present in $12(66 \%)$ of these 18 patients. In three cases, the margins of the lesions were not clearly defined, and there were lucent areas within the lesion itself. Information regarding medullary invasion and soft tissue retention (marrow involvement, soft tissue extension) could be obtained only for 17 of the 42 patients. Medullary invasion and soft tissue retention were identified in four $(23.5 \%)$ of these 17 lesions. Due to their radiological features, the major challenge was differentiating these lesions on the long bones from radiologically similar conditions, especially from malignant bone tumors, such as parosteal, classic osteosarcoma and chondrosarcoma. Taking into account the data in the literature, and based on our own opinion, we believe that this lesion observed in the long bones consists, clinically and radiologically, of four phases, and that the radiological imaging of these lesions varies according to location and stage. Initially, the lesion is located in the soft tissue adjacent to the bone, with no continuity between the lesion and the bone cortex. This stage (stage I) is similar to the radiological and clinical findings of myositis ossificans [8, 19, 20]. The lesion then begins to grow slowly, forming a radiolucent line (zone) between the lesion and the adjacent cortex. In this stage (stage II), the radiological and clinical findings are similar to those of parosteal osteosarcoma $[5,20]$. In the next stage (stage III) $[11,12]$, and the lesion comes into contact with the cortex. Cortical thickness or cortical destruction then begins to develop. The clinical and radiological findings are similar to those of florid reactive periostitis and periosteal malignant bone tumors. In the last stage (stage IV) [10, 17], and the lesion causes cortical perforation, along with medullary invasion. The radiological and clinical findings are similar to those of malignant bone tumors, such as osteosarcoma and conventional chondrosarcoma.

There is no disagreement regarding the histopathological features of the lesion. Histologically, the lesions are characterized by three components: a cellular cartilaginous cap, an unusual mineralized cartilaginous matrix and a fibrovascular stroma $[1,2]$. Histologically, BPOP presents as a cartilagecapped exostosis. The cap is cellular with focal atypia, and the subchondral area is composed of fibrovascular tissue. The presence of an unusual form of calcified cartilage that stains blue on hematoxylin and eosin stain is characteristic. This feature, which has come to be known as "blue bone", was first noted by Meneses et al [2]. The absence of cellular atypia helps distinguish this lesion from malignant bone tumors, such as osteosarcoma and chondrosarcoma.

Many factors have been implicated in the etiopathogenesis of Nora's lesion. Some authors have attempted to reclassify Nora's lesion as a neoplastic process [9], and a specific genetic translocation has been identified [21, 22]. Some authors believe that the initiating event is trauma with subsequent subperiosteal hematoma [20]. Some authors have claimed the existence of a continuum between florid reactive periostitis (FRP), BPOP, and turret exostosis [23]. In some 
Table 3. Applied Surgical Technique for Lesions and Results

\begin{tabular}{|c|c|c|c|c|c|c|c|}
\hline $\begin{array}{l}\text { No. of } \\
\text { papers }\end{array}$ & Diagnosis & Treatment & $\begin{array}{l}\text { Time and No. of } \\
\text { recurrence }\end{array}$ & $\begin{array}{l}\text { Recurrence } \\
\text { treatment }\end{array}$ & Complication & $\begin{array}{l}\text { Follow-up } \\
\text { (months) }\end{array}$ & Result \\
\hline 1 & HE & Excision & 10 months & Second IE & No & 26 & NR \\
\hline 2 & $\mathrm{HE}$ & Excision & ND & & $\begin{array}{l}\text { Popliteal } \\
\text { aneurysm }\end{array}$ & ND & ND \\
\hline 3 & HE & Excision & ND & & No & ND & ND \\
\hline \multirow[t]{2}{*}{4} & $\mathrm{HE}$ & Not defined & 3 years & Excision & No & ND & ND \\
\hline & $\mathrm{HE}$ & Excision & No & No & No & ND & ND \\
\hline \multirow[t]{2}{*}{5} & $\mathrm{HE}$ & Not defined & No & No & No & 12 & NR \\
\hline & $\mathrm{HE}$ & Not defined & No & No & No & 60 & NR \\
\hline 6 & $\mathrm{HE}$ & M. Resection & No & No & No & 24 & NR \\
\hline 7 & ND & Not defined & $\mathrm{ND}$ & ND & ND & ND & ND \\
\hline \multirow[t]{5}{*}{8} & $\mathrm{HE}$ & Shark-bite & ND & ND & ND & ND & NR \\
\hline & & Shave exc. & & & & & \\
\hline & & M. Resection & & & & & \\
\hline & & M. Resection & & & & & \\
\hline & & M. Resection & & & & & \\
\hline 9 & $\mathrm{HE}$ & W. Resection & No & No & No & 24 & NR \\
\hline 10 & $\mathrm{HE}$ & W. Resection & No & No & No & 24 & NR \\
\hline 11 & $\mathrm{HE}$ & M. Resection & No & No & AVN & 42 & NR \\
\hline 12 & $\mathrm{HE}$ & Excision & Four time & $\begin{array}{l}\text { Wide } \\
\text { excision }\end{array}$ & No & 18 & NR \\
\hline 13 & $\mathrm{HE}$ & Excision & No & No & No & 48 & NR \\
\hline 14 & $\mathrm{CT}$ & No surgery & No surgery & No surgery & No surgery & No surgery & No surgery \\
\hline 15 & $\mathrm{HE}$ & M. Resection & No & No & No & 12 & NR \\
\hline 16 & $\mathrm{HE}$ & Not defined & ND & ND & ND & ND & ND \\
\hline \multirow[t]{3}{*}{17} & $\mathrm{HE}$ & M. Resection & No & No & No & 90 & NR \\
\hline & & $\begin{array}{l}\text { Curettage } \\
\text { LAT }\end{array}$ & No & No & No & 10 & NR \\
\hline & & $\begin{array}{l}\text { Curettage } \\
\text { LAT }\end{array}$ & No & No & No & 12 & NR \\
\hline 18 & $\mathrm{HE}$ & Excision & ND & No & Fibrosarcoma & ND & ND \\
\hline
\end{tabular}

HE: histopathologicexamination; LAT: local adjuvant therapy; ND: not defined; NR: no recurrence; IE: intralesional curetage.

cases, with available follow-up imaging, Dhondt et al [13] noticed a radiographic evolution, from the more characteristic FRP to BPOP, and finally, to turret exostosis. In support of this theory, Sundaram et al [15] reported a series of three patients with presumptive diagnoses of FRP based on radiological findings. These lesions were allowed to progress, and imaging findings were suggestive of BPOP. However, histo- logical correlation for each imaging stage was not available. Within the context of the review performed in our study, no histopathological study in support of this theory could be found. Our view is that trauma could be the triggering factor for Nora's lesion, as $9 \%$ of the 21 patients questioned in this study had a positive history of trauma. On the other hand, this lesion may have findings that are radiologically and clin- 
ically similar to other lesions, such as MO, FRP, osteochondroma and turret exostosis. However, we do not agree with the view that this lesion represents an intermediate stage of other lesions, such as MO, FRP, osteochondroma and turret exostosis. This is because we believe that BPOP has the radiological stages mentioned above, and that each stage bears the histopathological characteristics of BPOP. One of our cases was stage III, while two others were stage IV. The diagnosis of each one of these lesions was confirmed with histopathological examination. Moreover, numerous case presentations identified at stages I and II are histopathologically diagnosed as BPOP [3-5, 24]. Stage I and III presentations of Nora's lesion have been reported in the literature; Abramovici et al [2] reported two cases. The first was a lesion in the femur, which also demonstrated cortical invasion (stage III), while the second case was localized entirely within the soft tissues, with no demonstrable attachment to the underlying bone (stage I). It was postulated that this second case might reflect a very early case of histologically proven BPOP that could have been confused with myositis ossificans.

As it is localized in the long bones, it is difficult to distinguish this lesion clinically and radiologically from many other tumors or tumor-like lesions. Differential diagnosis considerations for this lesion include myositis ossificans, turret exostosis, florid periostitis, osteochondroma and osteosarcoma. The main differential diagnosis to be considered is myositis ossificans. This non-neoplastic lesion generally occurs adjacent to the larger muscles following trauma, and it has a centripetal pattern of ossification. It is difficult to distinguish this lesion radiologically and clinically from stage I Nora's lesion; therefore, it must be distinguished according to histological criteria. When a cartilaginous component is present, it is distributed haphazardly. Turret exostosis and florid periostitis are related reactive processes of the bone that can have characteristics radiologically similar to BPOP. The cortical and medullary continuity in osteochondroma is uniform and without interruption. Radiologically, they can mimic malignant tumors, such as osteosarcoma and chondrosarcoma. It is sometimes difficult to obtain a differential diagnosis for these tumors clinically and radiologically, thus necessitating a histopathological examination for proper identification. Although it is known that this lesion is more commonly localized in the short, tubular bones within the skeletal system, we nevertheless believe that this lesion is not as uncommon to the long bones as is generally presumed. In this context, we believe that difficulties are experienced in its diagnosis due to its ability to mimic many different types of lesions radiologically. As such, a multidisciplinary approach to diagnosis will likely result in the best outcome for the patient.

One of the most significant problems encountered with this disease is treatment. Reporting of this lesion in the long bones is particularly uncommon, with most reports being performed as case presentations. Among the rare case pre- sentations that are reported, the lack of a common language regarding the applied treatment techniques, along with the fact that views regarding the disease etiology and the natural course of the disease are limited to assumptions, precludes the development of a common perspective regarding the treatment of this disease. There are many points that need to be answered regarding the treatment process. First of all, should the lesion be treated? Second, should the lesion be monitored? Third, if surgery is to be performed, which surgical technique should be applied? In this study, surgical treatment was conducted in all cases except one. However, despite the fact that nearly all papers are presented in a case report format, no detailed information was provided regarding the applied surgical techniques, nor was a common language used regarding the applied surgical techniques. Despite all these shortcomings, it is now known that this disease involves lesions that may be potentially progressive. Based on the currently available information, it is difficult to assess beforehand which types of lesions are capable of progression. Furthermore, although progression has been reported in BPOP, no cases of regression or spontaneous healing have been reported. As such, surgical resection should be the preferred treatment method, without resorting to disease monitoring. Due to the lack of local adjuvant therapy options, and the aggressive nature of the disease, Nora's lesions continue to pose a challenge for orthopedic surgeons. Therefore, caution must be exercised when selecting the surgical technique to be performed. Techniques such as wide resection, marginal resection, intralesional excision and curettage have been suggested for the surgical treatment of Nora's lesion. Intralesional excision and curettage appear to involve a high risk of local recurrence on the lesions observed in the small bones; therefore, these techniques should not be performed for the surgical treatment of the lesion. On the other hand, due to the high recurrence rate and occasionally atypical histological appearance of the lesion, we also believe that it is necessary to avoid wide resection techniques that might require serious reconstructive surgeries and which have high mortality rates, as no malignant transformations, metastases, deaths, or associated systemic diseases have been described thus far for patients with BPOP.

Our lack of sufficient knowledge and experience regarding this lesion, along with the fact that a common language has not been used when describing the treatment of reported cases, precludes us from presenting optimal information regarding the treatment of this disease. However, our opinion is that marginal resection might be sufficient for the treatment of this disease. By this, we mean a marginal excision that includes the resection of the reactive zone. This technique involves the removal of the pseudocapsule and periosteum, the decortication of underlying abnormal host bone, and the administration of intralesional curettage and local adjuvant therapy to the medullary component. Depending on its stages, we believe that the surgical technique to be admin- 
istered in stages I and II of the lesion is marginal resection, while the administration of local adjuvant therapy (phenol and cauterization) in addition to marginal resection should be sufficient for stages III and IV.

Lesions observed in the small bones have a remarkable tendency to recur. Recurrence rates between $29 \%$ and $55 \%$ in a 2-year interval have been reported, and almost half of these patients experienced a previous second recurrence [1, 2]. No recurrence rates have been reported to date for lesions localized in the long bones. In this study, local recurrence was observed in three of 16 lesions. One of these recurrences was successfully treated with wide resection, while the other two were successfully treated with marginal resection.

\section{Conclusion}

In light of the currently available information, the radiological and clinical diagnosis of this lesion appears to be difficult and complex. This is because the clinical and radiological appearance of the disease varies according to its stage, and it can mimic the radiological features of nearly all bone tumors. In this regard, the gold standard for disease diagnosis is histopathological examination. In this study, no spontaneous recovery was reported. We consider Nora's lesion to be an aggressive lesion that causes cortical destruction and medullary infiltration, and which, by nature, is not self-limiting unless treated.

\section{References}

1. Nora FE, Dahlin DC, Beabout JW. Bizarre parosteal osteochondromatous proliferations of the hands and feet. Am J Surg Pathol. 1983;7(3):245-250.

2. Meneses MF, Unni KK, Swee RG. Bizarre parosteal osteochondromatous proliferation of bone (Nora's lesion). Am J Surg Pathol. 1993;17(7):691-697.

3. Abramovici L, Steiner GC. Bizarre parosteal osteochondromatous proliferation (Nora's lesion): a retrospective study of 12 cases, 2 arising in long bones. Hum Pathol. 2002;33(12):1205-1210.

4. Bush JB, Reith JD, Meyer MS. Bizarre parosteal osteochondromatous proliferation of the proximal humerus: case report. Skeletal Radiol. 2007;36(6):535-540.

5. Vlychou M, Gibbons CL, Rigopoulou A, Ostlere SJ, Athanasou NA. Bizarre parosteal osteochondromatous proliferation of the clavicle. J Shoulder Elbow Surg. 2008; 17(4):e18-20.

6. Kissel CG, McQuaid M, Lucas DR, Sundareson AS, Klimecki RS. Bizarre parosteal osteochondromatous proliferation. An unusual bone tumor. J Am Podiatr Med Assoc. 1995;85(6):301-305.

7. Michelsen H, Abramovici L, Steiner G, Posner MA. Bizarre parosteal osteochondromatous prolif- eration (Nora's lesion) in the hand. J Hand Surg Am. 2004;29(3):520-525.

8. Berber O, Dawson-Bowling S, Jalgaonkar A, Miles J, Pollock RC, Skinner JA, Aston WJ, et al. Bizarre parosteal osteochondromatous proliferation of bone: clinical management of a series of 22 cases. J Bone Joint Surg Br. 2011;93(8):1118-1121.

9. Joseph J, Ritchie D, MacDuff E, Mahendra A. Bizarre parosteal osteochondromatous proliferation: a locally aggressive benign tumor. Clin Orthop Relat Res. 2011;469(7):2019-2027.

10. Rybak LD, Abramovici L, Kenan S, Posner MA, Bonar F, Steiner GC. Cortico-medullary continuity in bizarre parosteal osteochondromatous proliferation mimicking osteochondroma on imaging. Skeletal Radiol. 2007;36(9):829-834.

11. Cooper PN, Malcolm AJ. A bizarre parosteal osteochondromatous proliferation of the radius. Histopathology. 1993;22(1):78-80.

12. Subasi M, Kapukaya A, Buyukbayram H, Bilici A. Unusual benign bone lesion simulating parosteal osteosarcoma. J Orthop Sci. 2006;11(5):529-532.

13. Dhondt E, Oudenhoven L, Khan S, Kroon HM, Hogendoorn PC, Nieborg A, Bloem JL, et al. Nora's lesion, a distinct radiological entity? Skeletal Radiol. 2006;35(7):497-502.

14. Hefferman EJ, Lee $\mathrm{CH}$, Alkubaiden FO, et al. Bizarre parosteal osteochondromatous proliferation of the ulna. Eur J Radiol Extra. 2008;66:e47-e50.

15. Choi JH, Gu MJ, Kim MJ, Choi WH, Shin DS, Cho KH. Fibrosarcoma in bizarre parosteal osteochondromatous proliferation. Skeletal Radiol. 2001;30(1):44-47.

16. Gruber G, Giessauf C, Leithner A, Zacherl M, Clar $\mathrm{H}$, Bodo $\mathrm{K}$, Windhager $\mathrm{R}$. Bizarre parosteal osteochondromatous proliferation (Nora lesion): a report of 3 cases and a review of the literature. Can J Surg. 2008;51(6):486-489.

17. Helliwell TR, O'Connor MA, Ritchie DA, Feldberg L, Stilwell JH, Jane MJ. Bizarre parosteal osteochondromatous proliferation with cortical invasion. Skeletal Radiol. 2001;30(5):282-285.

18. Bhalla VK, Coulson H, Parker W, Wynn J, Pipkin WL, Howell CG, Toscano M, et al. Popliteal pseudoaneurysm caused by Nora's lesion of the femur in a young child: a rare presentation and first report. J Pediatr Surg. 2012;47(12):e55-59.

19. Boudova L, Michal M. Atypical decubital fibroplasia associated with bizarre parosteal osteochondromatous proliferation (Nora's reaction). Pathol Res Pract. 1999;195(2):99-103; discussion 104.

20. Ly JQ, Bui-Mansfield LT, Taylor DC. Radiologic demonstration of temporal development of bizarre parosteal osteochondromatous proliferation. Clin Imaging. 2004;28(3):216-218. 
21. Zambrano E, Nose V, Perez-Atayde AR, Gebhardt M, Hresko MT, Kleinman P, Richkind KE, et al. Distinct chromosomal rearrangements in subungual (Dupuytren) exostosis and bizarre parosteal osteochondromatous proliferation (Nora lesion). Am J Surg Pathol. 2004;28(8):1033-1039.

22. Nilsson M, Domanski HA, Mertens F, Mandahl N. Molecular cytogenetic characterization of recurrent translocation breakpoints in bizarre parosteal osteochondromatous proliferation (Nora's lesion). Hum
Pathol. 2004;35(9):1063-1069.

23. Sundaram M, Wang L, Rotman M, Howard R, Saboeiro AP. Florid reactive periostitis and bizarre parosteal osteochondromatous proliferation: pre-biopsy imaging evolution, treatment and outcome. Skeletal Radiol. 2001;30(4):192-198.

24. Kershen LM, Schucany WG, Gilbert NF. Nora's lesion: bizarre parosteal osteochondromatous proliferation of the tibia. Proc (Bayl Univ Med Cent). 2012;25(4):369371 . 